\title{
Evaluasi Penggunaan Antibiotik pada Pasien Sepsis Neonatus di Rumah Sakit X Purwakarta
}

\section{Evaluation of Antibiotic Use in Neonatus Sepsis Patients in X Purwakarta Hospital}

Rani Hendiyani ${ }^{1 *}$, Wawaimuli Arozal ${ }^{1,2}$, Hesty Utami Ramadaniati ${ }^{1}$

${ }^{1}$ Program Studi Pasca Sarjana, Fakultas Farmasi, Universitas Pancasila, Jakarta, Indonesia

${ }^{2}$ Departemen Farmakologi \& Teraupetik, Fakultas Kedokteran, Universitas Indonesia, Indonesia

*Corresponding author: ranihendiyani@gmail.com

Submitted: 16 September 2020

Accepted: 2 July 2021

Published: 30 November 2021

\begin{abstract}
Background: The high morbidity and mortality rates in neonates are caused by sepsis. Bacteria is one of the causes, so that antibiotics are one of the empirical therapies. Irrational use of antibiotics can cause bacteria to become resistant, so that the goal of therapy is not optimal. Objectives: This study aimed to evaluate the antibiotics used by neonatal sepsis patients in terms of quality (Gyssens method) and quantity (Defined Daily Dose method) and to determine the relationship between drug rationale and length of stay using the Spearman Rank correlation test. Methods: This research was observational research with a Cross-sectional designed and analysed using the descriptive-analytic method. Prospective patient data collection from May-July 2019 obtained 67 medical records that met the inclusion criteria. Results: The evaluation of the quality of antibiotics, it was found that 26 patients (37.7\%) of the use of appropriate antibiotics were correct and 43 patients were incorrect, including $56.5 \%$ inaccurate doses of antibiotics, $4.3 \%$ because there were other antibiotics that were more effective and $1.4 \%$ the existence of antibiotics too long while the quantity of antibiotics use was 12.9 DDD/100 patient days including Ampicilin Sulbactam (3.25), Cefoperazone Sulbactam (4), Meropenem (2.42) while the value DDD exceeding WHO standard values were gentamicin (1.94) and Amikacin (1.29). Correlation results found $r=0.223(P \geq 0.05)$, indicating that the correlation between rational use of drugs with the length of stay was low. Conclusion: Inappropriate use of antibiotics still exists with quantities exceeding WHO standards.
\end{abstract}

Keywords: neonatal sepsis, antibiotics, gyssens method, DDD (defined daily dose) method, rank Spearman correlation test

\begin{abstract}
Abstrak
Pendahuluan: Angka morbiditas dan mortalitas yang tinggi pada neonatus disebabkan oleh sepsis. Bakteri sebagai salah satu penyebabnya sehingga antibiotik menjadi salah satu terapi empiris. Penggunaan antibiotik yang tidak rasional dapat menyebabkan bakteri menjadi resisten sehingga tujuan terapi tidak optimal. Tujuan: Penelitian ini bertujuan mengevaluasi antibiotik yang digunakan oleh pasien sepsis neonatus baik dilihat dari kualitas (metode Gyssens) maupun kuantitas (metode Defined Daily Dose) serta untuk mengetahui hubungan antara rasionalitas obat dengan lama rawat menggunakan uji korelasi Rank Spearman. Metode: Penelitian observasional berdesain potong lintang yang di analisis secara deskriptif analitik. Pengumpulan data pasien secara Prospektif dari bulan Mei - Juli 2019 diperoleh 69 rekam medis yang memenuhi kriteria inklusi. Hasil: Dari hasil evaluasi kualitas antibiotik diperoleh penggunaan antibiotik tepat sebanyak 26 pasien $(37,7 \%)$ dan tidak tepat sebanyak 43 pasien meliputi 56,5\% dosis pemberian antibiotik tidak tepat, 4,3\% karena terdapat antibiotik lain yang lebih efektif dan $1,4 \%$ adanya pemberian antibiotik terlalu lama sedangkan kuantitas penggunaan antibiotik diperoleh total 12,9 DDD/100 pasien-hari meliputi Ampisilin-sulbaktam 3,25 DDD/100 pasien-hari, Sefoperazone-sulbaktam 4 DDD/100 pasien-hari, Meropenem 2,42 DDD/100 pasien-hari sedangkan nilai DDD yang melebihi nilai standar WHO yaitu Gentamisin 1,94 DDD/100 pasien-hari dan Amikasin 12,9 DDD/100 pasien-hari meliputi Ampicilin-
\end{abstract}


Sulbaktam $(3,25)$, Cefoperazone Sulbaktam (4), Meropenem $(2,42)$ sedangkan nilai DDD yang melebihi nilai standar WHO yaitu gentamicin $(1,94)$ dan Amikasin $(1,29)$. Hasil korelasi diperoleh nilai $r=0,223(P \geq 0,05)$ yang artinya korelasi rendah bahwa tidak menunjukkan adanya hubungan antara rasional obat dengan lama rawat. Kesimpulannya: Penggunaan antibiotik yang tidak tepat masih ada dengan kuantitas melebihi standar WHO.

Kata kunci: sepsis neonatus, antibiotik, metode gyssens, metode DDD (defined daily dose), uji korelasi rank Spearman

\section{PENDAHULUAN}

Setiap tahun terdapat 5 juta kematian neonatus berdasarkan data perkiraan World Health Organization (WHO) (1996), yang terdiri dari 34/1000 kelahiran hidup sebagai angka mortalitas neonatus (kematian dalam 28 hari pertama kehidupan) dan 98\% kematian tersebut berasal dari negara berkembang. Angka kejadian sepsis neonatus di negara berkembang masih lebih tinggi (1,8 - 18/1000 kelahiran hidup), dibandingkan di negara maju (4 - 5/1000 kelahiran hidup) (Wilar dkk., 2016). Dalam laporan WHO yang di kutip dari State of the world's mother 2007 (data tahun 2000 - 2003), dikemukakan bahwa 36\% dari kematian neonatus disebabkan oleh penyakit infeksi, diantaranya: sepsis, pneumonia, tetanus dan diare. Di beberapa rumah sakit rujukan di Indonesia seperti RS Cipto Mangunkusumo Jakarta periode Januari - September 2005 kasus sepsis neonatus sebesar 13,68\% sedangkan angka kematian berkisar antara 14 - $18 \%$ (Depkes RI, 2007).

Bakteri, virus, parasit atau jamur merupakan kuman-kuman penyebab infeksi berat yang mengarah pada terjadinya sepsis. Salah satu kuman yang paling sering menyebabkan sepsis adalah bakteri (Lubis dkk, 2013), maka diperlukan antibiotik untuk jenis terapinya. Apabila antibiotik yang diberikan tidak tepat dapat menyebabkan dampak yang merugikan misalnya resistensi terhadap bakteri meningkat, timbul efek samping yang tidak dikehendaki dan biaya yang harus dikeluarkan jadi meningkat (Kemenkes RI, 2016).

Berdasarkan hasil penelitian Haryani \& Apriyanti (2016) di RSUP Fatmawati Jakarta pada periode Januari - Februari 2016 dari 42 sampel diperoleh hasil bahwa sepsis neonates dominan dialami oleh bayi laki-laki sebanyak 61,9\%, dengan Berat Bayi Lahir Rendah (BBLR) 69,1\%, 59,5\% persalinannya secara saecar, $64,3 \%$ dengan umur kehamilan prematur dan $81 \%$ terjadi pada sepsis awitan dini. Penggunaan antibiotik terbanyak adalah antibiotik Amoksisillin-Gentamisin sebanyak 38 pasien, diikuti Cefotaksim-Mikasin (25 pasien) atau Fosfomycin $\mathrm{Na}$ (1 pasien), dan Ceftazidim (14 pasien) atau Meropenem (12 pasien). Sebanyak
40,5\% dosis antibiotik yang diberikan tidak rasional (21,5\% kurang dari dosis yang seharusnya dan $19 \%$ lebih dari dosis yang seharusnya) disebabkan penggunaannya yang terlalu lama ( $>14$ hari) dan terlalu singkat ( $<7$ hari). Penelitian lain dari Aprisa (2019) di RSUD DR. Soetomo pada ruang NICU IGD, diperoleh hasil bahwa dari 35 pasien yang paling banyak menggunakan antibiotik kombinasi Ampisilin dan Gentamisin (57,14\%). Gentamisin merupakan antibiotik dengan nilai DDD tertinggi yaitu 3,58 DDD/100 pasienhari artinya dari 100 pasien yang dirawat terdapat 4 pasien yang menggunakan antibiotik $0,24 \mathrm{~g}$ Gentamisin setiap harinya dan nilai total DDD diperoleh 10,93 DDD/100 pasien-hari.

Menurut data laporan tahunan di Rumah Sakit X tahun 2018 jumlah pasien sepsis neonatus meningkat 13\% dibandingkan tahun 2017. Angka kejadian sepsis neonatus menunjukkan bahwa penyakit sepsis neonatus menduduki urutan ke-2 setelah penyakit neonatus hiperbilirubin. Penelitian ini bertujuan untuk mengetahui antibiotik yang digunakan pasien sepsis neonatus baik dari kualitas maupun kuantitasnya.

Berdasarkan data tersebut maka penulis tertarik untuk melakukan penelitian di Rumah Sakit X, yang bertujuan untuk mengetahui karakteristik pasien sepsis neonatus, mengetahui penggunaan antibiotik terutama kualitas dan kuantitasnya, mengetahui hubungan outcome klinis dengan lama rawat.

\section{BAHAN DAN METODE Bahan}

Rekam medis pasien sepsis neonatus yang sedang di rawat di ruang rawat inap neonatal Rumah Sakit X pada periode Mei - Juli 2019.

Alat

Alur Gyssen untuk menentukan kualitas antibiotik yang digunakan, Rumus perhitungan DDD (Defined Daily Dose) untuk menentukan kuantitas antibiotik yang digunakan.

\section{Metode}

Sebelum melakukan penelitian ini, penulis mengajukan izin etik penelitian ke Komite Etik di RS. 
Esnawan Jakarta dan memperolehnya dengan Nomor Sket/05/V/2019/ KEPK.

Penelitian ini dilakukan dari bulan Mei s/d Juli 2019 di ruang rawat inap neonatal Rumah Sakit X terhadap antibiotik yang digunakan pasien sepsis neonatus. Penelitian ini merupakan jenis penelitian observasional dengan analisis secara deskriptif analitik, menggunakan desain potong lintang. Populasi yang diteliti adalah pasien sepsis neonatus yang memenuhi kriteria inklusi, yaitu pasien dengan data rekam medis lengkap, pasien bayi usia $<28$ hari dengan sepsis neonatus dengan atau tanpa penyakit penyerta, mendapat antibiotika empiris paling sedikit 2 hari. Selain itu memiliki data karakteristik pasien (jenis kelamin, berat badan bayi sewaktu lahir, berat badan bayi sewaktu sepsis, usia bayi saat sepsis, jenis sepsis, penyakit penyerta, lama masa kehamilan, riwayat ibu pada saat persalinan).

Pengumpulan data dilakukan dengan pencatatan data sesuai kebutuhan penelitian menggunakan form pencatatan data. Kemudian data tersebut di analisa secara kuantitif (metode DDD/Defined Daily Dose) dan kualitatif (metode Gyssens).

\section{HASIL DAN PEMBAHASAN}

Pasien yang menjadi subjek penelitian selama periode Mei - Juli 2019 berjumlah 80, baik yang berasal dari persalinan di luar maupun yang lahir di Rumah
Sakit X. Seluruh pasien sepsis neonatus dan menerima pengobatan dengan menggunakan antibiotik. Dari 80 pasien tersebut hanya 67 pasien yang masuk kriteria inklusi karena 13 pasien lainnya dikeluarkan dari subjek penelitian dengan alasan pulang paksa/atas permintaan sendiri (APS) sebanyak 9 pasien, lama perawatan $<2$ hari sebanyak 2 pasien dan rujukan dari rumah sakit lain yang telah mendapat antibitotika sebanyak 2 pasien.

Berdasarkan penelitian ini, dari 67 pasien untuk jenis kelamin pada pasien sepsis neonatus yang disajikan pada Tabel 1 diperoleh bahwa jenis kelamin paling banyak yaitu laki-laki sebanyak 37 pasien $(55,2 \%)$ sedangkan jenis kelamin perempuan sebanyak 30 pasien $(44,8 \%)$. Bayi yang mengalami sepsis paling banyak berjenis kelamin laki-laki. Hal tersebut berhubungan dengan faktor pertahanan tubuh yang bersifat sex-linked, satu gen yang berlokasi di kromosom X. MikroRNA yang terdapat dalam kromosom $\mathrm{X}$ adalah suatu molekul yang meregulasi protein yang dibutuhkan untuk sistem imunitas (Desai dkk., 2014). Bayi laki-laki memiliki satu kromosom X dan satu kromosom Y (XY) sedangkan bayi perempuan memiliki dua kromosom X (XX). Kromosom yang lebih banyak inilah yang menyebabkan fungsi pertahanan bayi perempuan terhadap infeksi lebih besar dibandingkan bayi laki- laki.

Tabel 1. Karakteristik klinis pasien sepsis pada neonatus

\begin{tabular}{lcc}
\hline \multicolumn{1}{c}{ Karakteristik } & \multicolumn{2}{c}{$\mathrm{n}=67$} \\
\cline { 2 - 3 } & Jumlah (n) & Persentase (\%) \\
\hline Jenis Kelamin & 37 & 55,2 \\
Laki-laki & 30 & 44,8 \\
Perempuan & & \\
Usia & 64 & 95,5 \\
1 hari & 2 & 3,0 \\
3 - 7 hari & 1 & 1,5 \\
21 hari & & \\
Berat Badan Pasien & 6 & 9,0 \\
BBLR (Bayi Berat Lahir Rendah) & 57 & 85,0 \\
BBLC (Bayi Berat Lahir Cukup) & 4 & 6,0 \\
BBLL (Bayi Berat Lahir Lebih) & & 95,5 \\
Jenis Sepsis Neonatal & 64 & 4,5 \\
SAD (Sepsis Awitan Dini) & 3 & 95,5 \\
SAL (Sepsis Awitan Lambat) & & 4,5 \\
Riwayat Usia Kehamilan & 64 & \\
CB (Cukup Bulan) & 3 & 10,4 \\
KB (Kurang Bulan) & & 89,6 \\
Penyakit Penyerta Bayi & 7 & 50,7 \\
Dengan Penyakit Penyerta & 60 & 49,3 \\
Tanpa Penyakit Penyerta & 34 & \\
Riwayat Persalinan & 33 & \\
Lahir normal & & \\
Bedah sesar & & \\
\hline
\end{tabular}


Penelitian lainnya banyak yang menunjukkan bahwa bayi laki-laki lebih banyak mengalami sepsis di bandingkan bayi perempuan namun sampai saat ini belum ada penelitian yang membuktikan apakah ada kaitannya antara jenis kelamin dengan sepsis neonatus (Rasfa dkk., 2015).

Berdasarkan usia diperoleh data $95,5 \%$ pada usia 1 hari, $3 \%$ pada usia antara 3 - 7 hari dan $1,5 \%$ pada usia 21 hari. Pasien neonatus dengan usia 1 hari menunjukkan persentase yang lebih tinggi karena pada saat persalinan sangat rentan terkena infeksi yang bersifat nosokomial. Selain itu, infeksi bisa juga terjadi melalui saluran genital ibu karena adanya organisme bakteri.

Berdasarkan berat badan bayi diperoleh Bayi Berat Lahir Cukup (BBLC) 85,1\% sedangkan yang lainnya 9\% dengan Bayi Berat Lahir Rendah (BBLR) dan 6\% dengan Bayi Berat Lahir Lebih (BBLL). Pada penelitian ini dimana bayi dengan BBLC lebih banyak sepsis. Hal ini dipengaruhi oleh faktor dari ibu yang mengalami koriamnionitis seperti ketuban pecah lama (> 18 jam), demam intrapartum ibu $\left(>38,4^{\circ} \mathrm{C}\right)$, leukositosis ibu, infeksi saluran kencing pada ibu dan infeksi karena kuman nosokomial. Menurut Wilar dkk. (2013), tidak terdapat hubungan yang bermakna antara sepsis neonatus dengan berat badan lahir pada bayi setelah dilakukan uji statistic.

Angka kejadian sepsis awitan dini diperoleh 95,5\% lebih banyak dibandingkan sepsis awitan lambat hanya memperoleh 4,5\%. Menurut Wilar dkk. (2009) dalam penelitiannya pada periode Januari - Juli 2009, setelah dianalisa yang menjadi penyebab sepsis awitan dini yaitu faktor-faktor yang berhubungan secara signifikan dengan sepsis neonatus salah satunya ketuban pecah dini > 18 jam. Pada penelitian ini, faktor yang menyebabkan SAD yaitu adanya korioamnionitis dan air ketuban berbau karena adanya data yang menunjukkan air ketuban yang berwarna hijau, keruh dan berwarna merah darah.

Menurut riwayat usia kehamilan diperoleh data kehamilan Cukup Bulan (CB) antara 37 - 42 minggu sebanyak 95,5\% atau 64 pasien dan Kurang Bulan (KB) kurang dari 37 minggu sebanyak 4,5\% atau 3 pasien. Pada penelitian ini usia kelahiran dengan cukup bulan dari 64 pasien sebanyak 33 pasien air ketubannya berwarna hijau, 4 pasien keruh dan 1 pasien berwarna merah darah. Hal ini membuktikan bahwa warna air ketuban berpengaruh pada sepsis dan tidaknya pada bayi. Bayi lahir dengan air ketuban berwarna hijau, keruh atau merah darah berisiko terjadinya sepsis 10 kali lebih besar bila dibandingkan dengan bayi lahir dengan air ketuban tidak keruh. Sebagai media kultur yang kurang baik bagi bakteri, air ketuban di tambah adanya sejumlah mekonium di dalamnya, dapat meningkatkan pertumbuhan bakteri terutama Escherichia coli dan Listeria monocytogenes. Air ketuban yang bercampur mekonium dapat menyebabkan janin berisiko lebih tinggi terinfeksi dibanding bayi yang lahir dengan air ketuban tidak keruh (Kosim dkk., 2010).

Pada penelitian ini pasien tanpa penyakit penyerta lebih banyak dibandingkan dengan penyakit penyerta yaitu sebanyak 60 pasien $(89,6 \%)$ sepsis neonatus tanpa penyakit penyerta sedangkan sebanyak 7 pasien $(10,4)$ sepsis neonatus dengan penyakit penyerta.

Riwayat persalinan normal lebih banyak yaitu $50,7 \%$ dibandingkan bedah saecar 49,3\%. Pada penelitian ini riwayat persalinan normal lebih banyak menjadi penyebab terjadinya sepsis neonatus. Hal ini menunjukkan bahwa bayi dengan sepsis terjadi karena tertular pada saat dalam kandungan dan pada saat proses persalinan (Manuaba, 2014). Penggunaan alat saat dilakukan pertolongan pada proses persalinan atau pada saat resusitasi merupakan salah satu penyebab sepsis neonatus karena adanya kontaminasi kuman yang terjadi setelah lahir (IDAI, 2009).

\section{Evaluasi kualitas penggunaan antibiotik}

Pada Tabel 2 terdapat 5 varian antibiotik yang diberikan kepada pasien sepsis neonatal baik tunggal maupun kombinasi. Ada 63 pasien (94\%) dari jumlah pasien menggunakan terapi antibiotik kombinasi lini pertama. 
Tabel 2. Golongan dan jenis antibiotik pada pasien sepsis neonates

\begin{tabular}{clcc}
\hline Lini & Golongan dan jenis antibiotik tunggal/kombinasi & Jumlah resep (R/) & Persentase (\%) \\
\hline 1 & $\begin{array}{l}\text { Penicilin dan Aminoglikosida } \\
\text { Ampisilin-sulbaktam dan Gentamisin }\end{array}$ & 63 & 1,5 \\
1,2 & $\begin{array}{l}\text { Cefalosporin dan Aminoglikosida } \\
\text { Ampisilin-sulbaktam dan Gentamisin, sefopurazone- } \\
\text { sulbaktam dan Amikasin }\end{array}$ & 1 & 1,5 \\
1,3 & $\begin{array}{l}\text { Karbapenem } \\
\text { Ampisilin-sulbaktam dan Gentamisin, Meropenem }\end{array}$ & 1 & 1,5 \\
2 & $\begin{array}{l}\text { Cefalosporin dan Aminoglikosida } \\
\text { sefopurazone-sulbaktam dan Gentamisin } \\
\text { Karbapenem } \\
\text { Meropenem }\end{array}$ & 1 & 1,5 \\
\hline & Jumlah & 67 & 100 \\
\hline
\end{tabular}

Penatalaksanaan sepsis neonatus di Rumah Sakit X, sebanyak 63 pasien (94\%) diberikan terapi antibiotik lini 1 Ampisilin-sulbaktam dan Gentamisin sebagai terapi awal sampai pasien tersebut di nyatakan sembuh. Hal ini telah sesuai dengan pedoman pelayanan medis IDAI (2009). Kemudian, ada 2 pasien yang diberikan antibiotik terjadi pergantian, yaitu 1 pasien $(1,5 \%)$ dari lini 1 ke lini 3, (Ampisilin + sulbaktam dan Gentamisin di ganti dengan Meropenem) dan 1 pasien (1,5\%) dari lini 1 ke lini 2 (Ampisilin + sulbaktam dan Gentamisin di ganti dengan Sefoperazone + sulbaktam dan Amikasin). Pergantian terapi sepsis neonatus dari lini 1 ke lini 2, telah sesuai dengan penatalaksanaan terapi untuk sepsis neonatus menurut Depkes RI (2007) yaitu apabila pasien memburuk selama 3 hari dilihat dari keadaan umum (KU) setelah diberikan antibiotik lini 1, maka antibiotik di ganti dengan antibiotik lini 2 yaitu Sefoperazone dan Amikasin. Sedangkan 1 kasus (1,5\%) menggunakan Sefoperazone + sulbaktam sebagai lini 2 di kombinasi dengan Gentamisin dan 1 kasus (1,5\%) pasien sepsis neonatus diberikan terapi Meropenem sebagai lini 3 .

Efek terapi dari penggunaan antibiotik tidak sama antara satu pasien dengan pasien yang lain tergantung pada kondisi klinik pasien yang ditunjukkan dengan KU semakin membaik atau semakin memburuk. Ini ditunjukkan pada adanya 1 pasien diberikan lini pertama kemudian karena KU tidak membaik diberikan lini ke tiga yaitu Meropenem tanpa pemberian lini ke dua terlebih dahulu. Selain itu ada juga pemberian langsung lini kedua yaitu sefopurazone-sulbaktam dan Gentamisin dan satu kasus lagi pemberian antibiotik langsung di berikan lini ke tiga yaitu Meropenem. Hal ini karena melihat KU yang memburuk serta nilai CRP yang melebihi nilai normal sehingga dengan cepat pasien diberikan lini ke dua atau ke tiga. Pemberian antibiotik ini tidak didukung dengan uji kultur sehingga terapi tidak berdasarkan pola kumannya hanya berdasarkan KU dan pemeriksaan hematologi di liat dari nilai kritisnya.

Durasi penggunaan antibiotik yang ditunjukkan pada Tabel 3 tersingkat adalah 3 hari sebanyak 24 pasien $(35,8 \%)$ telah sesuai dengan Kementrian Kesehatan Republik Indonesia (2011) bahwa lama pemberian antibiotik kombinasi antara $48-72$ jam (2 - 3 hari). Durasi penggunaan antibiotik terbanyak adalah $4-7$ hari sebanyak 42 pasien $(63,7 \%)$ dan $>7$ hari (19 hari) dengan jumlah 1 pasien (1,5\%), tidak sesuai prinsip penggunaan terapi antibiotik kombinasi menurut Kementrian Kesehatan Republik Indonesia (2011). Jika lebih dari 3 hari (> 72 jam), harus di observasi dengan melakukan pemeriksaan untuk kondisi klinis pasien, pemeriksaan berdasarkan data mikrobiologis dan data penunjang lainnya. Hal ini tidak dilakukan untuk data mikrobiologis dan penunjang lainnya dikarenakan keterbatasan biaya dalam menangani pasien sepsis neonatus. Kebanyakan pasien sepsis neonatus adalah pasien BPJS dimana pengambilan data mikrobiologis membutuhkan biaya yang besar. 
Tabel 3. Durasi pemberian antibiotik pada pasien sepsis neonatus

\begin{tabular}{|c|c|c|c|c|c|c|c|c|}
\hline Penggunaan antibiotik & $\begin{array}{c}\text { Durasi } \\
3 \text { hari }\end{array}$ & $\%$ & $\begin{array}{c}\text { Durasi } \\
4-7 \text { hari }\end{array}$ & $\%$ & $\begin{array}{c}\text { Durasi } \\
>7 \text { hari }\end{array}$ & $\%$ & Jumlah Pasien & $\%$ \\
\hline $\begin{array}{c}\text { antibiotik Lini 1 } \\
\text { Ampisilin-sulbaktam dan } \\
\text { Gentamisin }\end{array}$ & 24 & 35,8 & 39 & 58,2 & & & 63 & 94 \\
\hline $\begin{array}{l}\text { antibiotik Lini 1, Lini } 2 \\
\text { Ampisilin-sulbaktam dan } \\
\text { Gentamisin, Sefoperazone- } \\
\text { sulbaktam dan Amikasin }\end{array}$ & & & 1 & 1,5 & & & 1 & 1,5 \\
\hline $\begin{array}{l}\text { antibiotik Lini 1, Lini } 3 \\
\text { Ampisilin-sulbaktam dan } \\
\text { Gentamisin, Meropenem }\end{array}$ & & & & & 1 & 1,5 & 1 & 1,5 \\
\hline $\begin{array}{l}\text { antibiotik Lini } 2 \\
\text { Sefoperazone-sulbaktam dan } \\
\text { Gentamisin }\end{array}$ & & & 1 & 1,5 & & & 1 & 1,5 \\
\hline $\begin{array}{c}\text { antibiotik Lini } 3 \\
\text { Meropenem }\end{array}$ & & & 1 & 1,5 & & & 1 & 1,5 \\
\hline Jumlah & 24 & 35,8 & 42 & 63,7 & 1 & 1,5 & 67 & \\
\hline
\end{tabular}

Selain membutuhkan biaya yang besar juga dibutuhkan waktu yang panjang sedangkan penanganan sepsis neonatus harus segera dilakukan dengan pemberian antibiotik. Jika KU memburuk setelah 3 hari diberikan antibiotik, maka antibiotik diganti dari lini pertama ke lini kedua. Efek dari penggunaan antibiotik yang tidak sesuai dengan pola kuman akan menimbulkan resistensi.

Tabel 4 menunjukkan ketepatan dosis penggunaan antibiotik yang diberikan kepada pasien sepsis neonatus. Pada penelitian ini terdapat 36 dosis dengan persentase $28 \%$ penggunaan antibitotika yang tepat, 20 dosis dengan persentase $16 \%$ penggunaan antibiotik yang lebih dari dosis seharusnya dan 71 dengan persentase $56 \%$ dosis penggunaan antibiotik yang kurang dari dosis yang seharusnya. Besarnya lebih dosis dan kurang dosis pada penelitian ini sebagian disebabkan karena sulitnya memberikan dosis yang tepat karena berat badan pasien sehingga dokter berinisiatif melakukan pembulatan pada dosis yang terdapat bilangan di belakang koma sehingga yang terjadi yaitu lebih atau kurang dari dosis yang seharusnya sehingga pemberian antibiotik menjadi tidak tepat.

Tabel 4. Ketepatan dosis penggunaan antibiotik pasien sepsis neonatus

\begin{tabular}{lcccc}
\hline & \multirow{2}{*}{ Total } & \multicolumn{3}{c}{ Pemberian Dosis } \\
\cline { 3 - 5 } & & Kurang & Tepat & Lebih \\
\hline Ampisilin-Sulbaktam & 66 & $24(36,4 \%)$ & $27(40,9 \%)$ & $15(22,7 \%)$ \\
Gentamisin & 66 & $56(84,8 \%)$ & $7(10,6 \%)$ & $3(4,5 \%)$ \\
Meropenem & 2 & - & - & $2(100 \%)$ \\
Sefoperazone-sulbaktam & 2 & - & $2(100 \%)$ & - \\
Amikasin & 1 & $1(100 \%)$ & - & - \\
\hline Jumlah & 127 & $71(56 \%)$ & $36(28 \%)$ & $20(16 \%)$ \\
\hline
\end{tabular}

Pada rute pemberian antibiotik untuk semua pasien sepsis neonatus melalui rute intravena sesuai dengan kondisi bayi baru lahir dimana pada bayi baru lahir pemberian antibiotik selain intravena tidak memungkinkan contohnya melalui rute oral. Selain itu dipilih rute secara intravena karena sepsis neonatus merupakan infeksi berat sehingga diperlukan bioavailabilitas yang tinggi untuk menyerang segala bentuk bakteri yang terdapat dalam jumlah yang banyak di dalam darah.
Lama perawatan atau Lenght of Stay (LOS) pada pasien sepsis neonatus menurut Tabel 5 dengan lama rawat $\leq 7$ hari yaitu 4 hari sebanyak 41 pasien atau $61 \%$, 5 hari sebanyak 14 pasien atau 20,9\%, 6 hari sebanyak 3 pasien atau $4.5 \%, 7$ hari sebanyak 2 pasien atau $3 \%$. Sedangkan $\geq 7$ hari yaitu 8 hari sebanyak 1 pasien atau $1.5 \%, 10$ hari sebanyak 1 pasien atau $1.5 \%, 14$ hari sebanyak 1 pasien atau $1.5 \%, 17$ hari sebanyak 1 pasien atau $1.5 \%$ dan 23 hari sebanyak 1 pasien atau $1.5 \%$. Jadi total pasien dengan lama rawat $\leq 7$ hari yang sesuai dengan Kementrian Kesehatan Republik Indonesia 
(2011) berjumlah 60 pasien atau 89,4\%. Hal ini menunjukkan bahwa lama rawat pasien sepsis neonatus di Rumah Sakit X telah sesuai dengan Kementrian Kesehatan Republik Indonesia (2011).

Tabel 5. Lama Rawat Inap atau Length of Stay (LOS)

\begin{tabular}{ccc}
\hline Lama & \multirow{2}{*}{ Jumlah pasien } & Persentase $(\%)$ \\
\hline Perawatan & 41 & 61 \\
5 - hari & 21 & 3,4 \\
$>7$ hari & 5 & 7.5 \\
\hline
\end{tabular}

Keberhasilan penggunaan antibiotik ditentukan oleh beberapa faktor seperti ketepatan dosis, cara pemberian, frekuensi pemakaian dan lama pemberian antibiotik. Hal ini di evaluasi dengan metode Meer \&
Gyssens (2001) yaitu metode evaluasi peresepan antibiotik dengan pendekatan kualitatif yang menilai 12 sub kategori dan dinyatakan dengan satuan peresepan.

Pada Tabel 6 menunjukkan hasil 26 pasien menggunakan antibiotik tepat (kategori 0), 39 pasien diberikan terapi dengan dosis antibiotik tidak tepat (kategoriIIa), tiga pasien dinyatakan ada antibiotik lain yang lebih efektif (kategori IVa) dan 1 pasien antibiotik diberikan terlalu lama (kategori IIIa). Pada kategori Iva yaitu satu pasien dengan pengobatan langsung dengan lini ke 3, satu pasien dengan pengobatan langsung lini ke 2 dan satu pasien dengan pengobatan dari lini ke 1 dilanjutkan ke lini 3 dan satu pasien menunjukkan pemberian antibiotik lebih dari tujuh hari.

Tabel 6. Evaluasi Penggunaan antibiotik berdasarkan metode Gyssens

\begin{tabular}{clcc}
\hline & \multicolumn{1}{c}{ Hasil metode Gyssens } & Jumlah pasien & $(\%)$ \\
\hline 0 & Penggunaan antibiotik tepat/bijak & 26 & 37,7 \\
IIa & Dosis pemberian antibiotik tidak tepat & 39 & 56,5 \\
IVa & Ada antibiotik lain yang lebih efektif & 3 & 4,3 \\
IIIa & Pemberian terlalu lama & 1 & 1,4 \\
\hline & Total & 69 & 100 \\
\hline
\end{tabular}

Penatalaksanaan terapi sepsis neonatus seharusnya dimulai dari lini pertama (Ampisilin-Gentamisin) jika tidak menunjukkan perbaikan maka di ganti dengan lini ke dua dan jika belum ada perbaikan maka diganti dengan lini ke 3 (Meropenem) dan pemberian antibiotik tidak lebih dari 7 hari karena hal ini akan menimbulkan resistensi terhadap antibiotic.

\section{Evaluasi kuantitas penggunaan antibiotik}

Pada penelitian ini durasi pemberian antibiotik yang paling banyak digunakan yaitu 3 - 4 hari sebanyak 93\%. Pada sebagian besar penyakit infeksi, antibiotik yang diberikan selama 5 - 7 hari. Hal ini kemungkinan karena antibiotik yang diresepkan dengan tujuan terapi empiris. Jangka waktu pemberian antibiotik secara empiris yaitu selama 48 - 72 jam atau 2 - 3 hari. Pemberian antibiotik secara empiris, di pilih antibiotik dengan spektrum luas seperti antibiotik golongan penisilin dan aminoglikosida.

Penilaian kuantitas penggunaan antibiotik dari 67 catatan medik pasien sepsis neonatus didapat dari perhitungan DDD/100 hari rawat. Kuantitas antibiotik yang digunakan semakin kecil menunjukkan bahwa dokter lebih selektif dalam peresepan antibiotik sehingga lebih mendekati prinsip penggunaan antibiotik yang rasional.

Dalam penelitian ini didapatkan lima jenis antibiotik dengan total 12,9 g DDD/100 hari rawat seperti yang ditunjukkan pada Tabel 7. Penggunaan antibiotik dengan nilai lebih tinggi dari pada standar nilai DDD WHO adalah Gentamisin dengan nilai sebesar 1,94 g DDD/100 hari rawat dan Amikasin dengan nilai sebesar 1,29 g DDD/100 hari rawat. Jika nilai DDD lebih tinggi dari standar nilai DDD yang dikeluarkan WHO, itu menunjukkan bahwa peresepan dan penggunaan antibiotik pada pasien kemungkinan tidak selektif sehingga di khawatirkan akan banyak ditemui antibiotik yang diresepkan dan digunakan pasien tidak tepat sehingga akan mempengaruhi kerasionalan antibiotik terutama kerasionalan ketepatan dosis. Ada 2 jenis antibiotik yang masuk ke dalam segmen DU 90\% penggunaan tertinggi yaitu Ampisilinsulbaktam dan Gentamisin. 
Tabel 7. Evaluasi penggunaan antibiotik pasien sepsis neonatus berdasarkan DDD 100 pasien-hari

\begin{tabular}{|c|c|c|c|c|c|c|c|}
\hline $\begin{array}{c}\text { Jenis } \\
\text { antibiotik }\end{array}$ & $\begin{array}{l}\text { Kode } \\
\text { ATC }\end{array}$ & $\begin{array}{c}\text { DDD WHO/100 } \\
\text { Hari Rawat } \\
\text { (gram) }\end{array}$ & $\begin{array}{c}\text { Pemberian } \\
\text { Dosis (gram) } \\
(n=67)\end{array}$ & $\begin{array}{c}\text { DDD } \\
\text { (gram) }\end{array}$ & $\begin{array}{c}\text { DDD/100 } \\
\text { patient-days }\end{array}$ & $\%$ & $\begin{array}{c}\text { Segmen } \\
\text { DU }\end{array}$ \\
\hline $\begin{array}{l}\text { Ampisilin- } \\
\text { sulbaktam }\end{array}$ & J01CA01 & 6 & 63,03 & 10,50 & 3,25 & 57,47 & \multirow[t]{3}{*}{$90 \%$} \\
\hline Gentamisin & J01GB03 & 0,24 & 1,51 & 6,29 & 1,94 & 34,37 & \\
\hline Meropenem & J01DH02 & 3 & 2,76 & 0,92 & 2,42 & 5,04 & \\
\hline $\begin{array}{l}\text { Sefoperazone- } \\
\text { sulbaktam }\end{array}$ & J01DD12 & 4 & 1,92 & 0,48 & 4 & 2,63 & \multirow[t]{2}{*}{$10 \%$} \\
\hline Amikasin & J01GB06 & 1 & 0,09 & 0,09 & 1,29 & 0,49 & \\
\hline Total & & & 69,31 & 18,28 & 12,9 & 100,0 & \\
\hline
\end{tabular}

\section{Outcome klinik setelah diberikan antibiotik}

Tabel 8 menunjukkan bahwa keadaan 67 pasien sepsis neonatus pada saat pulang dinyatakan $100 \%$ dalam kondisi sembuh. Pasien dinyatakan sembuh apabila tanda dan gejala sepsis sudah tidak muncul, hasil pemeriksaan penunjang, terjadi perbaikan seperti pada umumnya, keadaan bayi baik, suhu tubuh normal, percepatan pernafasan normal dan denyut nadi kembali normal.

Hubungan antara rasionalitas antibiotik dengan lama rawat dan outcome klinisnya

Pada Tabel 9 didapat hasil dari obat yang rasional sebanyak 19 pasien $(28,4 \%)$ dengan lama rawat $\leq 4$ hari dan 7 pasien $(10,4 \%)$ dengan lama rawat antar 5 - 7 hari. Hal ini sudah sesuai dengan pedoman dari Kementrian Kesehatan Republik Indonesia (2011) bahwa untuk pengobatan pasien infeksi adalah maksimal 7 hari. Sedangkan yang tidak rasional sebanyak 41 pasien $(61,2 \%)$ dengan lama rawat $\leq 4$ hari, 21 pasien $(31,3 \%)$ dengan lama rawat 5 - 7 hari dan 5 pasien $(7,5 \%)$ dengan lama rawat $>7$ hari. Penggunaan antibiotik yang tidak rasional akan menyebabkan resistensi.

Tabel 8. Keadaan pasien saat keluar dari rumah sakit

\begin{tabular}{ccc}
\hline \multirow{2}{*}{ Karakteristik } & \multicolumn{2}{c}{$\mathrm{n}=67$} \\
\cline { 2 - 3 } & $\begin{array}{c}\text { Jumlah } \\
(\mathrm{n})\end{array}$ & $\begin{array}{c}\text { Persentase } \\
(\%)\end{array}$ \\
\hline $\begin{array}{c}\text { Keadaan Sewaktu Pulang } \\
\text { Sembuh }\end{array}$ & 67 & 100,0 \\
\hline
\end{tabular}

Tabel. 9 Hubungan antara rasionalitas obat dengan lama perawatan

\begin{tabular}{|c|c|c|c|}
\hline \multirow{2}{*}{ Lama Perawatan } & \multicolumn{2}{|c|}{ Rasionalitas Obat } & \multirow{2}{*}{ Total $(\%)$} \\
\hline & Rasional (\%) & Tidak Rasional (\%) & \\
\hline$\leq 4$ hari & $19(28,4 \%)$ & $22(32,8 \%)$ & $41(61,2 \%)$ \\
\hline $5-7$ hari & $7(10,4 \%)$ & $14(20,9 \%)$ & $21(31,3 \%)$ \\
\hline 5 - 7 hari & 0 & $5(7,5 \%)$ & $5(7,5 \%)$ \\
\hline
\end{tabular}

Hasil dari uji Rank Spearman Tabel 10 menunjukkan nilai $\mathrm{r}=0,223(\mathrm{P}>0,05)$ artinya korelasi rendah hal ini menunjukkan bahwa variabel yang di uji tidak menunjukkan hubungan antara rasionalitas obat dengan lama perawatan karena signifikasi hasil korelasi lebih besar dari $0,05 \quad(5 \%)$. Hasil korelasi ini mengartikan bahwa antara penggunaan antibiotik yang rasional tidak ada hubungannya dengan seseorang lebih cepat atau lama dalam penyembuhan. Tidak adanya hubungan antara rasionalitas dengan seseorang lebih cepat atau lebih lama dalam penyembuhan karena evaluasi yang digunakan adalah literatur IDAI dan KEMENKES. 
Tabel 10. Hasil Uji Rank Spearman

\begin{tabular}{|c|c|c|c|}
\hline \multicolumn{4}{|c|}{ Correlations } \\
\hline & & & RO - LOS \\
\hline \multirow{6}{*}{ Spearman's rho } & \multirow{3}{*}{ Rasionalitas Obat } & Koefisien korelasi & 1 \\
\hline & & Sig. (2-tailed) & . \\
\hline & & Jumlah populasi $(\mathrm{N})$ & 67 \\
\hline & \multirow{3}{*}{ Lama Perawatan } & Koefisien korelasi & 0.223 \\
\hline & & Sig. (2-tailed) & 0.07 \\
\hline & & Jumlah populasi (N) & 67 \\
\hline
\end{tabular}

\section{KESIMPULAN}

Profil pasien terbanyak sepsis neonatus adalah bayi laki-laki dengan usia 1 hari, Berat Lahir Cukup (BBLC), jenis Sepsis Awitan Dini, usia kehamilan Cukup Bulan (CB), tanpa penyakit penyerta dan persalinan normal. Golongan dan jenis antibiotika yang sering digunakan adalah kombinasi Ampisilin-sulbaktam dan gentamicin dengan persentase $94 \%$, rute pemberian melalui intravena dan durasi paling banyak 4 - 7 hari. Hasil evaluasi kualitas penggunaan antibiotik diperoleh $38,8 \%$ penggunaan antibiotik tepat, $56,7 \%$ dosis pemberian antibiotik tidak tepat dan $4,5 \%$ terdapat antibiotik lain yang lebih efektif. Sedangkan untuk evaluasi kuantitas penggunaan antibiotik di peroleh antibiotik dengan standar nilai DDD lebih tinggi dari standar nilai DDD yang di keluarkan WHO yaitu Gentamisin dan Amikasin. Outcome klinik pasien sepsis neonatus setelah pemberian antibiotik dinyatakan sembuh. Hasil statistik dari uji Rank Spearman di peroleh nilai $r=0,223(\mathrm{P}>0,05)$ artinya korelasi rendah. menunjukkan bahwa rasionalitas obat tidak ada hubungan dengan lama rawat.

Dari hasil penelitian ini, untuk selanjutnya perlu dilakukan penelitian dengan uji kultur untuk mengetahui pola kuman sehingga penggunaan antibiotik untuk sepsis neonatus bisa rasional dan perlu dilakukan evaluasi penggunaan antibiotika secara berkala khususnya pada pasien sepsis neonatus yang ada di Rumah Sakit X Purwakarta.

\section{UCAPAN TERIMA KASIH}

Penelitian ini bisa selesai dilaksanakan berkat dukungan dari pembimbing baik di Rumah Sakit X Purwakarta maupun di kampus Fakultas Farmasi Magister Ilmu Kefarmasian Universitas Pancasila Jakarta.

\section{DAFTAR PUSTAKA}

Aprisa, N. (2019). Studi Penggunaan Antibiotik Secara Kuantitatif pada Pasien yang Dirawat di NICU IGD RSUD Dr. Soetomo. Skripsi; Fakultas
Farmasi Universitas Katolik Widya Mandala, Surabaya.

Departemen Kesehatan Republik Indonesia (Depkes RI) (2007). Penatalaksanaan Sepsis Neonatorum. Health Technology Assesmen Indonesia. Jakarta: Depkes RI.

Desai, P., Shah, A. N. \& Pandya, T. (2014). C-reactive Protein, Immature to Total Neutrophil Ratio and Micro ESR in Early Diagnosis of Neonatal Sepsis. International Journal of Biomedical and Advance Research; 5; 364-66

Haryani, S. \& Apriyanti, F. (2016). Evaluasi Terapi Obat Pada Pasien Sepsis Neonatal di Ruang Perinatologi RSUP Fatmawati Januari - Februari Tahun 2016. Jurnal Fatmawati Hospital; 1; 1-10. Ikatan Dokter Anak Indonesia (IDAI) (2009). Sepsis Neonatal. Pedoman Pelayanan Medis Ikatan Dokter Anak Indonesia. Surabaya: IDAI.

Kementrian Kesehatan Republik Indonesia. (2011). Pedoman Pelayanan Kefarmasian untuk Terapi Antibiotik. Jakarta: Kementrian Kesehatan Republik Indonesia.

Kementrian Kesehatan Republik Indonesia (Kemenkes RI). (2016). Pedoman Umum Penggunaan Antibiotik (Peraturan Menteri Kesehatan NO 72 TAHUN 2016). Jakarta: Kementrian Kesehatan Republik Indonesia.

Kosim, M. S., Rini, A. E. \& Suromo, L. B. (2010). Faktor Risiko Air Ketuban Keruh terhadap Kejadian Sepsis Awitan Dini pada Bayi Baru Lahir. Sari Pediatri; 12; 135-141

Lubis, B. M., Nelly, Syofiani, B., Sianturi, P., Azlin, E. \& Tjipta, G. D. (2013). Hubungan Kultur Darah Pasien Tersangka Sepsis dengan NilaiP rokalsitonin dan C-Reactive Protein. Sari Pediatri; 15; 5-8.

Manuaba, I. B. G. (2014). Ilmu Kebidanan Penyakit Kandungan dan Keluarga Berencana. Jakarta: EGC.

Rasfa, R. A., Oyong, N. \& Fatmawati. (2015). Uji Diagnostik Pemeriksaan C-reaktif Protein (CRP) 
pada Neonatus Tersangka Sepsis yang Dirawat di Instalasi Neonatus RSUD Arifin Achmad Provinsi Riau. Jurnal Online Mahasiswa; 2; 4-5.

Meer, V. J. W. M. \& Gyssens, I. C. (2001). Quality of Antimicrobial Drug Prescription in Hospital. Clinical Microbiology and Infection; 7; 12-15.

WHO. (1996). Perinatal Mortality (Report No: WHO /FRH/MSM/967). Geneva: WHO.

Wilar, R., Daud, D., As'ad, S., Febriani, D. B. \& Mina. (2016). A Comparison of Neutrophil GelatinaseAssociated Lipocalin and Immature to Total
Neutrophil Ratio for Diagnosing Early-Onset Neonatal Sepsis. Paediatrica Indonesiana; 56; 107-110.

Wilar, R., Kumalasari, E., Suryanto, D. Y. \& Gunawan, S. (2009). Faktor Risiko Sepsis Awitan Dini. Sari Pediatri; 12; 265-269.

Wilar, R., Mantix, M., Lihawa, M. Y. (2013). Hubungan Jenis Persalinan dengan Kejadian Sepsis Neonatorum di RSUP Prof. DR. R. D. Kandou Manado. E-Clinic; 2; 1-5. 